\title{
The Use of Javanese Traditional Games as Learning Media of Writing Javanese Script in The Elementary School
}

\author{
Joko Sukoyo $^{1}$, Esti Sudi Utami ${ }^{2}$, Endang Kurniati ${ }^{3}$ \\ $\left\{\right.$ 1j_sukoyo@mail.unnes.ac.id, ${ }^{2}$ esti.sudiutami@mail.unnes.ac.id, \\ 3endangkurniatijawa@mail.unnes.ac.id\} \\ 1,2,3 Javanese Language and Literature Department, Faculty of Language and Art, \\ Universitas Negeri Semarang
}

\begin{abstract}
According to the results of the field observations, many elementary school students in Central Java still had difficulty in reading and writing Javanese script. It was caused by teachers' tendency to use the teacher-centered approach in teaching. This approach led the students into being passive. They also felt bored during the learning process. Besides, the use of a teachercentered approach created one-way learning which was unable to trigger students' critical thinking. Based on the finding explained above, some efforts to stimulate Javanese script learning at the elementary level need to be made. One of which is by improving the learning method. The learning method has to be fun and meaningful. Fun learning or so-called joyful learning in this study was conducted by involving traditional Javanese game activities in the learning process. Traditional games which can be used as a learning medium for Javanese script is $A B C 5$ Dasar game. The use of $A B C 5$ Dasar game in learning to write Javanese script has many benefit such as (1) being used as a medium for memorizing Javanese characters in a fun way, (2) reducing student anxiety in learning, (3) making learning more meaningful, (4) motivating students not to be afraid of being wrong in writing Javanese script, (5) fostering a sense of solidarity and cooperation, and (6) creating impressive learning which is memorable for the students.
\end{abstract}

Keywords: game, traditional, script, Javanese

\section{Introduction}

Javanese characters (script) is the second script used by approximately 71 million citizens of Yogyakarta, Central Java and East Java [1] Javanese script is one of valuable Javanese cultural heritage. It has high aesthetic and spiritual values as noble teaching of manners. Javanese script has shown the culture and civilization of Javanese people to the world. Unfortunately, along with the development of the era, the noble Javanese script is rapidly neglected by the younger generation. Many young people are unable to read and write Javanese script even though they are learning Javanese in elementary to middle school level [2] One of the problems found Javanese learning is the students' difficulty in pronouncing and differentiating 
among carakan, pasangan, and sandhangan script [3]. Many students find it difficult to read and write Javanese script because teachers tend to use the lecture method in the learning process. By using the lecture method, communication in the learning process is done one-way. It does not allow interaction between teacher and student. As a result, students are less enthusiastic about learning Javanese. Besides, Javanese script learning is still domination by a teacher-centered approach. The teachers considered themselves as the subject of the learning while the students are the objects.

From the prior observation and interviews, the teachers and elementary school students in Central Java claimed that learning Javanese script was considered difficult because it was no longer used as a medium for daily literacy. The time allocated for learning Javanese script was also lacking. This was because learning to write or read Javanese scripts was integrated with Javanese subject which was only given a time allocation of 1-2 hours per week. Also, many students found it difficult to concentrate. They also did not have a strong motivation to learn Javanese script.

Based on the explanation above, an effort to stimulate learning to read and write Javanese script needs to be made. One of which is by improving the learning method. The method needed is a learning method which is fun and meaningful. One of fun learning or joyful learning is by involving traditional Javanese game activities in learning. Through the game, learning can be more fun [4]. Students tend to be interested in something that makes them happy. The use of the traditional game in the learning process is a creative idea to motivate students in learning. Thus, learning objectives can be achieved.

The traditional game is a typical game that is passed down from generation to generation [5] . Traditional game is usually passed down orally. It made without the help or intervention of high-tech toys. Equipment used in traditional games usually can be accessed easily from the surroundings such as bamboo, paper, wood, soil, plant stems, leaves, straw, and stones.

Traditional game has many benefits, including: creating a joyful atmosphere with togetherness, making children to get to know each other, making closer and stronger kinship ties, passing down knowledge and abilities from the previous generation (parents) to the next generation (children), realizing children abilities, and improving physical, cognitive, language, social-emotional, and artistic development [6].

Various traditional games in Central Java can be used in the learning process such as $A B C$ 5 dasar, jamuran, benteng-bentengan, boi-boian, bekelan, congklak, engklek, gobak sodor, kasti, nekeran, lumpatan, hompimpa et cetera. Although our country has various traditional games, they are slowly replaced by technological devices such as mobile phones, Play Station, television, and so forth. Indeed, in the Industrial 4.0 era, technological advances were so rapid. Moreover, almost all learning media are currently IT-based. However, it is undeniable that good media do not always come from IT. Cultural heritage possessed by each region can be used as media for example by utilizing traditional games in the learning process.

\section{Research Method}

The method used in this research is the qualitative one, for the purpose of developing learning method of writing javanese traditional script integrated with javanese traditionalgames. Data collection techniques used in this research are interview, observation and document analysis. Hence, the data are the analyzed using Miles and Huberman analysis model with the stages of data reduction, data display, conclusion, and verification [7]. 


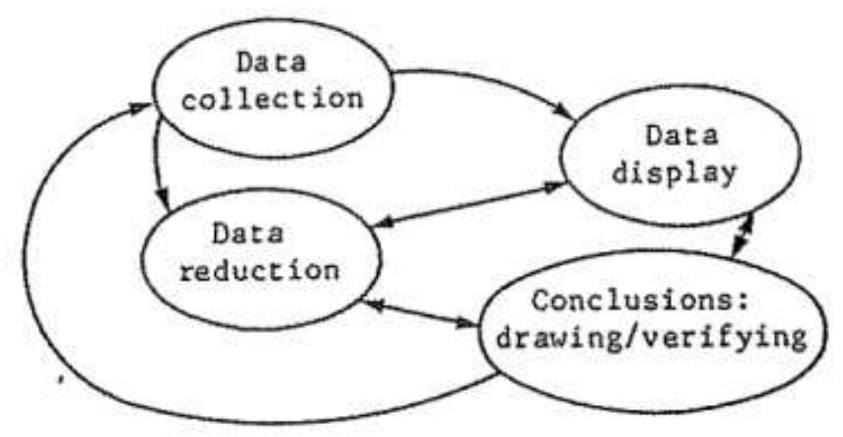

Fig 1. Components of Data Analysis: Interactive Model

\section{Result And Discussion}

Game is an entertaining, fun, and challenging activity where students can play and interact with one another [8]. Game is often said to be the world of children. Ref [9] defined game as an activity with rules, objective, and element of fun. Through games, children can express their feeling. Besides, the game is a medium to improve certain skills and abilities in children. Decades of research have shown that play is an important mediator in the physical, cognitive, and social emotional of young children [10], [11], [12]. Traditional games also stimulate motor skill in children [13].

In general, the game can be classified into two types namely digital and non-digital games [14]. An example of a non-digital game is a traditional game. A traditional game that exists in Central Java which can be used as a learning medium for writing Javanese script for elementary school students is $A B C 5$ Dasar game. The use of $A B C 5$ Dasar in learning Javanese script has many benefits including (1) being a medium to memorize Javanese characters in a fun way, (2) reducing student anxiety in learning, (3) creating meaningful learning, (4) motivating the students not to be afraid of being wrong in writing Javanese script, (5) fostering a sense of solidarity and collaboration, and (creating impressive learning process which is memorable for the students. The following is an overview of ABC 5 Dasar game.

A. The origin of the game

$A B C 5$ Dasar originates from the Central Java region. This game also developed in areas around Central Java such as Yogyakarta and East Java.

B. Participants

$A B C 5$ Dasar game is usually played by elementary school children, aged 4 to 11 years.

C. Number of participants

The number of participants ranges from 2 to 5 children. However, it allows more than 5 children to play.

D. Gender of participants

$A B C 5$ Dasar game can be played by boys and girls.

E. Equipment

It does not require specific equipment. It only requires a shady place to play such as on the terrace of the house or garden.

F. The game 
$A B C 5$ Dasar game is a form of wordplay including guessing the names of objects, animals, or characters such as the names of heroes in turn according to the agreement among players at the beginning of the game. This game will be reconstructed and used as a medium for learning Javanese script especially writing Javanese script at the elementary school level. The procedures for learning Javanese script by using $A B C 5$ Dasar game and the basic results of the reconstruction are as follows.

(1) The teacher prepares the supplementary materials for the game.

(2) The teacher explains the rules of the game.

(3) Students are divided into groups consisting of 4 to 6 people.

(4) Each group looks for the most comfortable place to play.

(5) Each group forms a circle position and says "Hompimpa alaium gambreng." After that, all students contribute their fingers freely such as five fingers, three fingers, and so on.

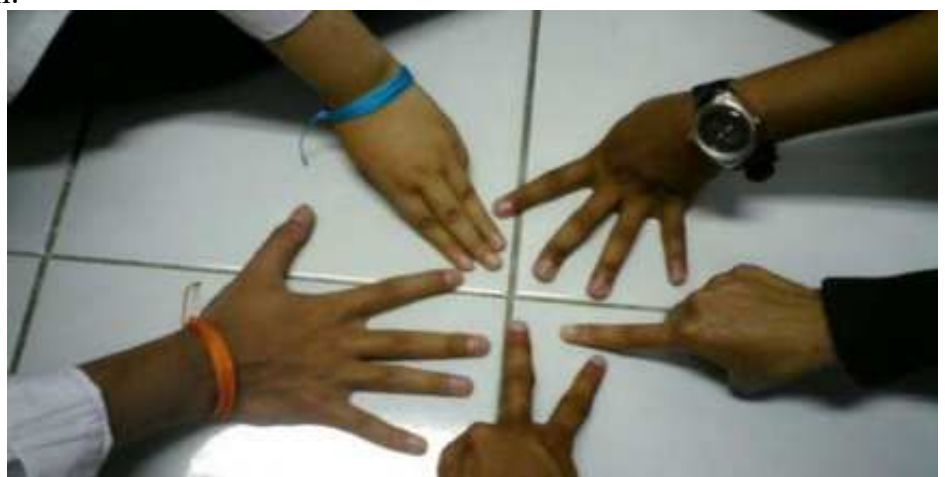

Fig 2. Students contribute their fingers. Source : https://www.fimela.com

(6) Student counts the number of fingers contributed by each student. The number of fingers then is sorted according to the Javanese characters, ha na ca ra ka da ta sa wa la pa dha ja ya nya ma ga ba tha nga. The alphabet used in Javanese script consists of 20 main character which are syllabic. This main character is often known as the "hanacaraka" script [15] as shown below.

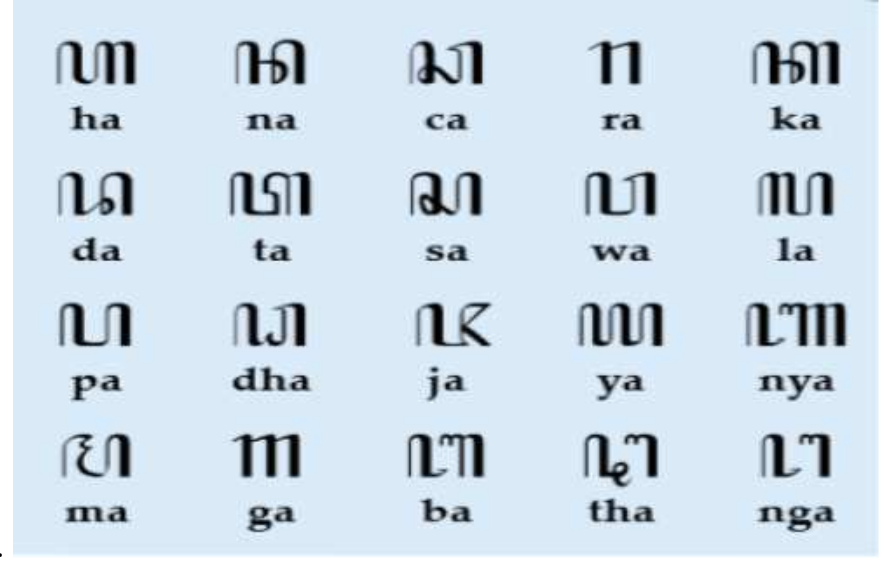

Fig 3. Hanacaraka Script 
For example, there are 4 students in one group. The first student contributes five fingers, the second student contributes two fingers, the third student contributes one finger, and the fourth student contributes three fingers. The number of fingers contributed by the four students is 11 . Then, that number is sorted by the Javanese characters. The 11th character in Javanese is the "pa" character.

(7) Students write a word that begins with "pa." The writing is made in Javanese script. For example, students write the words "palawija", "pakarti", "pakaryan" and so on.

(8) Each student writes the word on a paper that has been prepared by the teacher. At the top of the paper, the student's name is written. Below is an example of a student's paperwork.

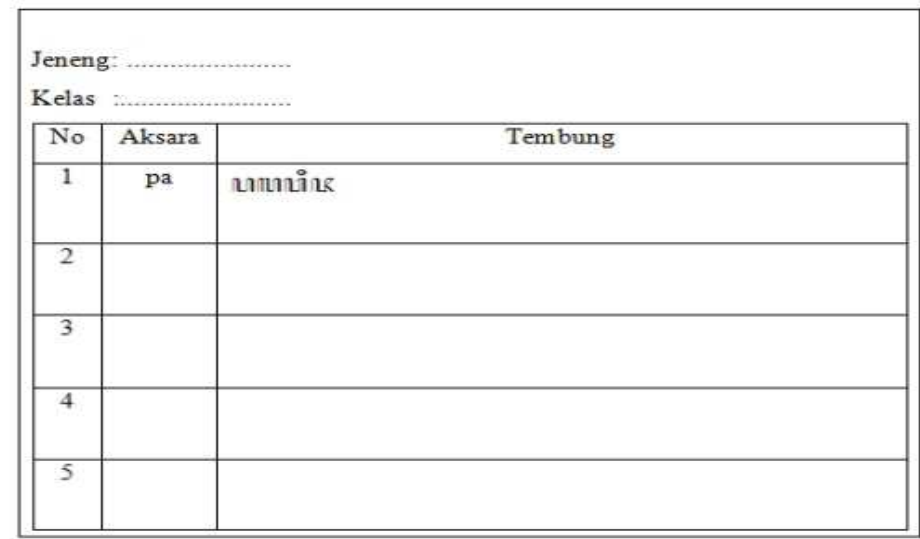

Fig 4. Student's Paperwork

(9) The game continues. For example, the first student contributes four fingers, the second student contributes eight fingers, the third student contributes three fingers, and the fourth student contributes three fingers. The number of fingers contributed by the four students is 18 . Then it is sorted by the Javanese characters. The 18th Javanese character is "ba."

(10) Students write a word that begins with the letter " $b a$." The writing made is Javanese script. For example, students write the words "bathi", "bathuk", "bali" and so on.

(11) Each student writes the word on the sheet/paper provided by the teacher.

(12) Students repeat the game in the time given by the teacher.

(13) Before ending the game, the teacher asks all students for their opinions about the game that has been done and asks what they have gained from the implementation of the game.

(14) The teacher reviews students' work, provides an assessment of their work, and conveys mistakes made by students. After that, the teacher gives an example of the correct one.

(15) The teacher determines the winner of the game. A student who wins the game is the student who has the highest score.

(16) The teacher concludes and closes the game. The teacher also gives prizes to the winner of the game [16]. 


\section{Conclusion}

The use of ABC 5 Dasar game as a learning medium for writing Javanese script is a form of a joyful learning concept. Joyful learning is a fun learning concept. In joyful learning, there are no pressure in learning, both physical and psychological pressures. The concept of fun learning is based on human nature which requires daily playtime, comfort, and entertainment. Joyful learning aims to make the students follow and feel the learning process with a pleasant and joyful atmosphere by being engaged with the learning process. Joyful learning also encourages students to be active. Students; activeness in learning makes them able to achieve optimal learning outcomes by the specified target. Learning to write Javanese script with joyful learning can be implemented by teachers at the primary school level, especially in the introduction of Javanese characters. This model gives students the freedom to explore their potentials. Children are not limited in a monotonous and saturating classroom atmosphere. Instead, they are welcome to study outside the classroom. Therefore, the students are not fixated on the classical learning process which only gives a lot of materials which is burdensome for students.

\section{References}

[1] E. Utami, "JawaTeX Web: Web Based Latin to Javanese Characters Transliteration System," Int. J. Comput. Sci. Emerg. Technol., vol. 60, no. 1, pp. 60-67, 2010.

[2] R. K. Dewi, et al., "Usability Evaluation of Mobile-Based Application for Javanese Script Learning Media," J. Inf. Technol. Comput. Sci., vol. 3, no. 1, pp. 88-93, 2018.

[3] O. Suria, "Development of Word Game Algorithm for Learning Javanese Script," CommIT (Communication Inf. Technol. J., vol. 12, no. 2, pp. 73-86, 2018.

[4] Y. H. Setiawan, "Designing Game 'Belajar Hanacaraka' As A Javanese Script Learning Media," Sisforma, vol. 4, no. 2, pp. 34-38, 2018.

[5] Y. K. S. Pranoto, S. Sugiyo and J. J. Hong, "Developing Early Childhood's Character Through Javanese Traditional Game," Indones. J. Early Child. Educ. Stud., vol. 3, no. 1, pp. 68-72, 2014.

[6] M. Satriana, "Permainan Tradisional Berbasis Budaya Sunda Sebagai Sarana Stimulasi Perkembangan Anak Usi Dini,” J. Pendidik. Anak Usia Dini, vol. 7, no. 1, pp. 65-84, 2013.

[7] M. B. Miles and A. M. Huberman, Qualitative Data Analysis. London: Sage Publication, 1994.

[8] A. Wright, D. Betteridge, M. Buckby, Games for Language Learning. New York: Cambridge University.

[9] J. Hadfield, Intermediate Grammar Games. England: Longman, 2003.

[10] Y. Gelisli and E. Yazici, "A Study into Traditional Child Games Played in Konya Region in Terms of Development Fields of Children," Procedia - Soc. Behav. Sci., vol. 197, no. February, pp. 1859-1865, 2015.

[11] P. I. Lestari and E. Prima, "The Implementation of Traditional Games to Improve the Social Emotional Early Childhood," J. Educ. Sci. Technol., vol. 3, no. 3, pp. 178-184, 2017.

[12] B. Bergen, "The Role of Pretend Play in Children's Cognitive Development," Early Child. Res. Pract., vol. 4, no. 1, 2002.

[13] A. Gipit, et al., "The Effect of Traditional Games Intervention Programme in the Enhancement School-age Children's Motor Skills: a Preliminary Study," Mov. Heal. Exerc., vol. 6, no. 2, pp. 157-169, 2017.

[14] N. K. Lai, et al., "The Impact of Play on Child Development a Literature Review," Eur. Early Child. Educ. Res. J., vol. 26, no. 5, pp. 625-643, 2018.

[15] Y. Sugianela and N. Suciati, "Character Image Segmentation of Javanese Script Using Connected Component Method,” J. Comput. Sci. Inf., vol. 12, no. 2, pp. 67-74, 2019. 
[16] N.K. Juliantari, I.K. Sudarsana, N.K. Sutriyanti, I.N.T. Astawa, I.D.A.H. Putri, and K. Saddhono. "Educational Games Based in Information Technology as Innovation Evaluation Activity in Learning." In IOP Journal of Physics: Conference Series, vol. 1114 no. 1, p. 012041. IOP Publishing, 2018. 